\title{
Assessment of Hepatorenal Function of Nigerian Solid Waste Scavengers in Osogbo, Nigeria
}

\author{
ADEBISI Wasiu Niyi ${ }^{1}$, ADEOYE Adebisi Cecilia ${ }^{1}$, OLUDE Solomon Suleiman ${ }^{1}$, \\ AKINDELE Funmilola Bolanle ${ }^{1}$ and IYANDA Ayobola Abolape ${ }^{2^{*}}$ \\ ${ }^{1}$ Department of Medical Laboratory Sciences, College of Health Sciences, Ladoke Akintola University \\ of Technology, Osogbo, Nigeria. \\ ${ }^{2}$ Department of Chemical Pathology, College of Health Sciences, Ladoke Akintola University of
} Technology, Osogbo, Nigeria.

Authors' contributions

This work was carried out in collaboration among all authors. All authors read and approved the final manuscript.

Article Information

DOI: $10.9734 / A R R B / 2022 / v 37 i 230486$

Open Peer Review History: This journal follows the Advanced Open Peer Review policy. Identity of the Reviewers, Editor(s) and additional Reviewers, peer review comments, different versions of the manuscript, comments of the editors, etc are available here: https://www.sdiarticle5.com/review-history/70211

Original Research Article

Received 19 May 2021

Accepted 21 July 2021

Published 20 February 2022

\begin{abstract}
Introduction: Both hepatic parenchymal and renal cells are rich in enzymes required for the biotransformation of various exogenous substances, a process that sometimes may result in organ damage. Contact with solid waste will undoubtedly result in high degree of exposure to various harmful substances. The aim of the study was to determine the impact of solid waste scavenging on hepato-renal function.

Material and Methods: Twenty-nine solid waste scavengers and 30 subjects who served as control were used for the study. Serum obtained from $5 \mathrm{~mL}$ of blood was utilized to assess hepatic (alanine \& aspartate aminotransferases, alkaline phosphatase, albumin, total protein, y-globulins) and renal (urea, creatinine) functions of each participant. Standard photometric methods were used for all estimations. Data were analyzed using Student's t-test and Pearson's correlation coefficient. P $\leq$ 0.05 was considered significant.

Results and Discussion: Significant differences were observed for globulins and total proteins in solid waste scavengers compared with control $(p<0.05)$ while other parameters (alanine \& aspartate aminotransferases, alkaline phosphatase, creatinine, urea) were not significantly different $(p>0.05)$. There was total non-compliance to the use of personal protective equipment. Results of the study revealed that hepatic and renal markers were not significantly different but $\mathrm{Y}$-globulins were
\end{abstract}


significantly higher in solid waste scavengers compared with control group.

Conclusion: Solid waste scavenging in Osogbo is not associated with hepatorenal alteration except that $\mathrm{Y}$-globulin fraction was elevated.

Keywords: Solid waste scavenging; liver; kidney; personal protective equipment.

\section{INTRODUCTION}

A major challenge in developing countries is uncontrolled urbanization, a situation which has been linked with high generation of waste beyond the ability of several municipalities to cope with. Through solid waste scavenging, the demand for waste evacuation in several communities is partly met. This widespread practice has also been recognized to meet the economic needs of those involved in this occupation [1-2]. In many developing countries, solid waste scavengers can be found on the streets or in open dumps or landfill areas [3]. Waste scavengers go from house to house and buy recyclable material like paper, plastic, glass and old clothes, thus preventing these things from going into dump sites. In the process they are subjected to a wide range of conditions, being exposed to different harmful substances [4]. Which as revealed by Sridevi et al. [5] may include industrial wastes, dead/decaying animals and in some communities fecal matter. If appropriate care is not observed, contact with solid waste may mitigate against the health and well-being of scavengers.

Studies have shown various types of hazard associated with scavenging, but there have been few studies done on health and injury incidence of informal sector waste workers (particularly scavengers) in most developing countries [6]. This situation is most apparent in Nigeria where investigations on occupational and public health impacts of wastes scavenging and informal sector recycling is hardly attempted. Hence the study was designed to investigate the impact of solid waste scavenging on hepatorenal function of Nigerian solid waste scavengers in Osogbo.

\section{MATERIALS AND METHODS}

\subsection{Study Design and Location}

This is a cross-sectional comparative study. The participants for the study were recruited at Ajegunle, Afonta and Sabo located in Olorunda Local Government, Osogbo with geographical coordinates $7^{0} 46^{1}$ North, $4^{0} 34^{1}$ East.

\subsection{Data Collection}

A well-structured questionnaire which had been pre-tested and was based on direct and indirect questions to obtain demographic characteristics such as age, sex, lifestyle, marital status, and education level was used. Behavioral characteristics as well as possible associated risk factors such as previous history of hepatic or renal disease, personal hygiene, and attitude towards the use of personal equipment were also recorded. Information was obtained about other factors such as smoking, consumption of alcohol, family history of hepatic and renal diseases, etc. The questionnaire was administered by a trained person.

\subsection{Inclusion/Exclusion Criteria}

Adult male Nigerians not more than 45 years of age, who have been solid waste scavengers for at least 12 months were included in the study. Control group was constituted by age-matched male Nigerians who have not been in waste disposal business. All participants that have had significant exposure to agents capable of causing hepatic and renal damage were excluded from the study. Those involved in intravenous drug use were excluded. The following characteristics were observed among the solid waste scavengers: poor working conditions, social stigmatization, high degree of poverty compared with the rest of the population, no or little education, or family enterprise, although some were recruitment by acquaintances.

\subsection{Sampling Technique and Sample Size}

Simple random sampling technique was used to recruit all participants. Sample size was 29 solid waste scavenger and 30 participants for control group. Since the study was designed to justify a research grant award and to enable the authors to plan for a larger study. According to Hertzog [7], a sample size of between 10 and 30 per group is adequate for a pilot study. 


\subsection{Sample Collection}

A total of $5 \mathrm{~mL}$ of blood was collected from each subject into anticoagulant free tube. Each blood sample was allowed to clot and retract. The serum was separated by centrifugation at 3000 rpm (Hettich ROTOFIX 32A centrifuge (Hettich Germany) for ten minutes to avoid hemolysis of the red blood cells. The serum samples were transferred safely into $2 \mathrm{~mL}$ cryovial and stored at $-20^{\circ} \mathrm{C}$ until needed for biochemical analyses.

\subsection{Biochemical Analyses}

Estimation of serum activities of AST and ALT was carried out as described by Reitman and Frankel [8] while that of ALP was according to the method of Babson et al. [9]. On the other hand, serum levels of albumin (bromocresol green), and total protein (biuret method) were determined as described by Doumas et al. [10] and Gomall et al. [11] respectively. Urea was estimated as described by Searcy et al. [12] and serum creatinine was by Jaffé reaction, but serum globulins were quantified by subtracting albumin concentration from that of total protein. Reagents (kits) were supplied by Randox ${ }^{\circledR}$. Spectrophotometer SP-1103 (manufactured by Axiom $\AA$, Germany) was used for this purpose.

\subsection{Statistical Analysis}

Descriptive statistics (mean \pm standard deviation) was used to summarize the results of markers of hepatorenal functions. Histogram was used to determine the distribution of the data obtained and was found to be normal in distribution. Therefore, parametric tests were used for data analysis. Student's t- test was used for data analysis, i.e. to compare the means of hepatorenal markers of solid waste scavengers and control group. Pearson's correlation coefficient was used to determine association between continuous variables. Statistical Package for Social Sciences (SPSS) version 15 was used for this purpose. $\mathrm{P} \leq 0.05$ was considered statistically significant.

\section{RESULTS}

Presented below are the results of the study. Table 1 shows the mean \pm standard deviation of indices of hepatic and renal damage of solid waste scavengers and that of the control group. There was no significant difference in the mean of albumin, AST (aspartate aminotransferase), ALT (alanine aminotransferase), ALP (alkaline phsphatase), urea and creatinine in solid waste scavengers (SWS) when compared to that of the control group $(p>0.05)$. There was a significant difference in the mean value of total protein and globulin in test subjects when compared to that of control group $(p<0.05)$. There was a positive significant correlation between total protein and globulin in the test subjects $(r=0.547, p=0.002)$ using Pearson's correlation coefficient. Summarized information on use of personal protective and lifestyle choices are presented in Table 2.

Table 1. Markers of hepato-renal function of solid waste scavengers and controls

\begin{tabular}{llll}
\hline Parameters & Test subjects $(\mathbf{n}=\mathbf{2 9})$ & Control subjects $(\mathbf{n = 3 0})$ & p-value \\
\hline Total protein $(\mathrm{g} / \mathrm{L})$ & $73.97 \pm 6.99$ & $69.67 \pm 7.43$ & $0.026^{*}$ \\
Albumin $(\mathrm{g} / \mathrm{L})$ & $41.00 \pm 5.87$ & $41.93 \pm 7.05$ & 0.583 \\
AST $(\mathrm{U} / \mathrm{L})$ & $15.03 \pm 9.90$ & $20.48 \pm 18.09$ & 0.160 \\
ALT $(\mathrm{U} / \mathrm{L})$ & $12.97 \pm 6.82$ & $11.67 \pm 8.22$ & 0.512 \\
ALP $(\mathrm{U} / \mathrm{L})$ & $23.86 \pm 12.94$ & $27.53 \pm 1.051$ & 0.169 \\
Urea $(\mathrm{mmol} / \mathrm{L})$ & $4.26 \pm 0.91$ & $4.20 \pm 1.05$ & 0.800 \\
Creatinine $(\mu \mathrm{mol} / \mathrm{L})$ & $91.45 \pm 15.96$ & $92.46 \pm 25.79$ & 0.857 \\
Globulin $(\mathrm{g} / \mathrm{L})$ & $32.83 \pm 5.4$ & $27.83 \pm 7.45$ & $0.005^{\star}$ \\
\hline
\end{tabular}

Results are summarized as mean \pm standard deviation. Abbreviations: AST, Aspartate Transaminase; ALT, Alanine Transaminase; ALP, Alkaline Phosphatase. * Significant at $p$-value $<0.05$

Table 2. Summary of demographic data of solid waste scavengers and controls

\begin{tabular}{lll}
\hline Items & Waste scavengers & Controls \\
\hline Lifestyle & & \\
Smoking (cigarette) & & \\
Yes & $(18 ; 62.07 \%)$ & $(13 ; 43 \%)$ \\
No & $(11 ; 37.93 \%)$ & $(17 ; 57 \%)$ \\
Alcohol consumption & &
\end{tabular}




\begin{tabular}{lll}
\hline Items & Waste scavengers & Controls \\
\hline Yes & $(4 ; 13.7 \%)$ & $(5 ; 17 \%)$ \\
No & $(25,86.3 \%)$ & $(25 ; 83 \%)$ \\
Intravenous drug use & & \\
No & $(29 ; 100 \%)$ & $(29 ; 100 \%)$ \\
Non-compliance to use of PPE & & \\
Apron & $(29 ; 100 \%)$ & $\mathrm{N} / \mathrm{A}$ \\
Boot & $(29 ; 100 \%)$ & $\mathrm{N} / \mathrm{A}$ \\
Gloves & $(29 ; 100 \%)$ & $\mathrm{N} / \mathrm{A}$ \\
Overall & $(29 ; 100 \%)$ & $\mathrm{N} / \mathrm{A}$ \\
\hline
\end{tabular}

\section{DISCUSSION}

The results of the present study show that there was no hepatic membrane damage occurring from waste scavenging as both aspartate transaminase (AST) and alanine transaminase $(A L T)$ were not significantly different in solid waste scavengers compared with control. Karim et al. [13] and Alimba et al. [14] identified a number of chemicals, elements and other toxic components in municipal waste. A few of them have been shown to cause obstructive jaundice which usually present as elevated alkaline phosphatase (ALP), yet the result of the present study did not identify obstructive liver disease in the waste scavengers as the levels of activity of ALP were not significantly different in both solid waste scavengers and control. Neither did the study of Odewabi et al. [15] reveal elevated ALP in solid waste disposal workers.

The non-significant difference in the levels of albumin in both scavengers and control group seems to buttress the absence of hepatic damage in solid waste scavengers. Albumin an important plasma protein is mostly employed to assess the synthetic ability of hepatic parenchymal cell. The results of albumin, AST and ALT seem to suggest that the functional integrity of the liver cells was not compromised. The significant increase in the level of globulins suggests infection, but since albumin was not significantly decreased it ruled out acute infections [16]. In acute infections proteins of acute inflammatory state are increased while others like albumin, transthyretin, and transferrin (called negative acute phase reactants) are decreased as a result of the inhibitory effects of interleukins 1 and 6 on the biosynthetic mechanism of negative acute phase proteins $[17,18]$. Therefore it will seem reasonable to suggest that the elevated globulins level in scavengers can be linked to chronic infection. In chronic infection $\mathrm{Y}$-globulin is usually elevated. This observation is in agreement with many earlier submissions. Many infectious diseases have been associated with scavenging and they include coughs, skin diseases, hepatitis, diarrhea, eye infection and parasitic infections.

Evidence for this assumption is supported by the report of Wachukwu and Eleanya [19]. They reported that lymphocyte counts for waste disposal workers were significantly higher than those of control. The fact that other parameters estimated by Wachukwu and Eleanya [19] especially hematological markers like hemoglobin $(\mathrm{Hb})$, white blood cells (neutrophils and monocytes), other cells derived from hematopoietic stem cells were reduced, showed that the abnormal globulin was more related to infection rather than generalized stimulation of hematopoietic stem cells. In addition, municipal waste workers have been reported to present with elevated levels of immunoglobulin A $(\lg A)$ and IgG [20]; although inflammatory markers were also increased.

Odewabi et al. [21] noted that renal markers were not significantly different in waste management workers compared with control, an observation that is in agreement with the result of the present study. Urea and creatinine were not significantly different in the solid waste scavengers compared with control indicating that the renal parenchymal cells were not affected. The mean values of creatinine and urea of these subjects that were not significantly different from that of the control subjects is also in accord with the report of Wilson and Waugh [22], who reported that solid waste disposal does not affect the level of creatinine and urea.

The results of exposure to waste in experimental animals are somewhat different with respect to renal and hepatic functions compared with human subjects. Wistar rats orally exposed to different concentrations of municipal landfill leachates exhibited absolute and relative increase in weight of liver and kidney. Moreover, 
both hepatic enzymes (AST and ALT) and renal markers (urea and creatinine) were significantly increased [14]. The differences in the result of Alimba et al. [14] and the present study in which non- significant differences between solid waste scavengers and control were observed may be linked with species differences. Differences in expression levels of enzymes that play a role in metabolism of xenobiotics in various mammalian species have been identified as important factor that determine degree of organ toxicity. Moreover, the differences in major route of exposure in the wistar rats and solid waste scavengers may also cause the differences in result outcomes. For the wistar rats leachates were prepared in different concentration and administered orally, the major route of contact to solid waste scavengers was probable dermal or nasal contact.

The possible usefulness of apron, boot and mask could not be determined since the hepatic and renal makers of group not using Personal Protective Equipment (PPE) could not be compared with those using any or all of them. But since the globulin level was significantly higher than control and PPE was not used by all the solid waste scavengers (i.e. $0 \%$ compliance), this further confirms that the increase in globulin fraction of total protein might be infection related. For many occupational types, the use of PPE is encouraged to prevent exposure to harmful substances [23]; and diverse materials capable of causing infection have also been identified in municipal waste [24-28].

\section{CONCLUSION}

The study raises the possibility that noncompliance with use of personal protective equipment may be widespread in Osogbo. Moreover, there are indications that hepato-renal dysfunction may not be a common manifestation of solid waste scavenging. The elevated globulin fraction observed requires further investigation.

\section{LIMITATIONS OF THE STUDY}

The study is limited by the fact that participants were recruited in Osogbo where there is no diversity of solid wastes. There are very few industries sited in this location, which means the effects of industrial wastes on hepato-renal markers could not be assessed. In addition, no data was collected on the types of infectious diseases present in the scavengers, therefore the cause of the elevated globulins could not be related to a particular disease.

\section{FURTHER STUDY}

From the present data collected, it becomes imperative to carry out further study:

1. To identify the source of elevated globulins by carrying out serum protein electrophoresis or immunoassay technique.

2. To collect data on type of infections present in solid waste scavengers

3. Consisting of a larger sample size of both male and female scavengers, in a location where all types of solid wastes (domestic, industrial, etc) are found.

\section{DISCLAIMER}

The products used for this research are commonly and predominantly use products in our area of research and country. There is absolutely no conflict of interest between the authors and producers of the products because we do not intend to use these products as an avenue for any litigation but for the advancement of knowledge. Also, the research was not funded by the producing company rather it was funded by personal efforts of the authors.

\section{ETHICAL APPROVAL AND CONSENT}

Ethical clearance was obtained from Ethical Committee of Ladoke Akintola University Technology (LAUTECH) Teaching Hospital Osogbo, Osun state. The subjects that participated in this research were duly informed about the project. Their consent was obtained before participation in the project. Concerning information obtained, strict confidentiality was maintained.

\section{COMPETING INTERESTS}

Authors have declared that no competing interests exist.

\section{REFERENCES}

1. Popoola OE, Popoola AO, Purchase D. Levels of awareness and concentrations of heavy metals in the blood of electronic waste scavengers in Nigeria. J. Health Pollut. 1903;9(21):11. 
2. Abati B, Hartard S, Bradl HB, Pishva D, Ahiakpa JK. Resource prospects of municipalsoid wastes generated in the $\mathrm{Ga}$ East municipal assembly of Ghana. J. Health Pollut. 2017;7(14):37-47.

DOI. 10.5696/2156-9614-7.14.37

3. Al-Khatib IA, Al-Sari MI, Kontogianni S. Assessment of occupational health and safety among scavengers in gaza strip, Palestine. J. Environ Public Health. 2020;2020:3780431.

DOI: $10.1155 / 2020 / 3780431$.

4. Akpeimeh GF, Fletcher LA, Evans BE. Exposure to bioaerosols at open dumpsite, Lagos Nigeria. Waste Manag. 2019;89: 37-47.

DOI: 10.1016/..wasman.2019.03.058

5. Sridevi V, Musalavah M, Chandana ML, Kesavarao VA. A review on integrated solid waste management. International Journal of Engineering Science and Advanced Technology. 2012;2(5): 1491-1499.

6. Cointreau S. Occupational and Environmental Health Issues of Solid waste Communications in Waste \& Resource Management (CWRM). 2000;9(1):24-30.

7. Hertzog $M$ A. Considerations in determining sample size for pilot studies. Research in Nursing and Health. 2008;31(2):180-91

8. Reitman S, Frankel S. Guidelines on standard operating procedure for clinical chemistry. American Journal of Clinical Pathology.1957;28(1):56-63.

Available:https://doi.org/10.1093/ajcp/28.1. 56PMid:13458125

9. Babson AL, Greeley SJ, Coleman CM, Philip GO. Phenolpthalein monophospate as a substrate for serum alkaline phosphate. Clinical Chemistry. 1966;12:481-490

10. Doumas B, Waston W, Biggs H. Albumin standard and measurement of serum albumin with Bromocresol green. International Journal of Clinical Chemistry and Diagnostic Laboratory Medicine. 1971;31:81.

11. Gomall A, Bordwill R, David M. Determination of serum proteins by means of Biuret reaction. Journal of Biology Chemistry. 1949;177:751 - 800.

12. Searcy RL, Reardon JE, Foreman JA Estimation of enzymatic urea. American Journal of Medicine Tech.1967;33:15-20. PMid:6037908
13. Karim R, Kuraoka M, Higuchi T, Sekine M, Imai T. Assessment of heavy metal contamination from municipal solid waste open dumping sites in Bangladesh. International Journal of Environment and Waste Management. 2017;19:191-202.

14. Alimba CG, Bakare AA, Aina OO. Liver and Kidney Dysfunction in Wistar Rats Exposed to Municipal Landfill Leachate. Resources and Environment 2012;2(4): 150-163.

Available:https://doi.org/10.5923/j.re.20120 204.04

15. Odewabi AO, Ogundahunsi OA, Ekor M. Effect of exposure to solid waste in relation to employment duration on some important markers of health and disease in waste management workers of Ogun state in southwest Nigeria. Human and Experimental Toxicology. 2013;32(2): 1231-44

Available:https://doi.org/10.1177/09603271 13488612PMid:23703821

16. Iyanda AA, Anetor Jl. Biomarkers of hepato-renal damage of fuel filling station attendants using or abstaining from use of protective gears. ACCLM. 2007;3(1):15-21. Available:http://dx.doi.org/10.3126/acclm.

17. Bologa RM, Levine DM, Parker TS, Cheigh JS, Serur D, Stenzel KH, Rubin AL. American Journal ofKidneyDiseases 1998;32(1):107-114.

Available:https://doi.org/10.1053/ajkd.1998 .v32.pm9669431PMid:9669431

18. Manani SM, Virzi G.M, Clementi A, Brocca $A$, de Cal M, Tantillo I, Ferrando L, Crepaldi C, and Ronco C. Proinflammatory cytokines: a possible relationship with dialytic adequacy and serum albumin in peritoneal dialysis patients. Clinical. Kidney Journal. 2016;9(1):153-157.

Available:https://doi.org/10.1093/ckj/sfv137 PMid:26798477 PMCid:PMC4720213

19. Wachukwu KC, Eleanya EU. Health Impact Assessment of Solid Waste Disposal Workers in Port Harocurt, Nigeria. Journal of Applied Sciences. 2007;7:3562-3566.

Available:https://doi.org/10.3923/jas.2007. 3562.3566

20. Odewabi AO, Ogundahunsi OA, Odewabi $A A$, Oritogun KS, Ekor M. Adenosine deaminase activity and immunoglobulin levels as potential systemic biomonitors of occupational hazards and health status in municipal solid waste management 
workers. Environ Toxicol Pharmacol 2013; 35(1):1-12.

Available:https://doi.org/10.1016/j.etap.201 2.11.002PMid:23228702

21. Odewabi AO, Ogundahunsi OA Ebesunu MO, Ekor M. The level of inflammatory markers and oxidative stress in individuals occupationally exposed to municipal solid waste in Ogun State, South West Nigeria. Toxicol Ind Health. 2013;29(9): 846-55.

Available:https//:doi:10.1177/07482337124 45043

22. Wilson DC, Velis C, Cheeseman C. Role of informal sector recycling in the environment. African Journal of Waste Recycling 2006;5(1):144-145.

23. Honda H, Iwata K. Personal protective equipment and improving compliance among healthcare workers in high-risk settings. Current Opinion in Infectious Diseases 2016;29(4):400-406.

Available:https://doi.org/10.1097/QCO.000 0000000000280PMid:27257793

24. Ayeleru OO, Okonta FN, Ntuli F. Municipal solid waste generation and characterization in the City of Johannesburg: A pathway for the implementation of zero waste. Waste Manag. 2018;79:87-97.
DOI:10.1016/j.wasman.2018.07.026.PMID: 30343815

25. Kumar A, Samadder SR, Kumar N, Singh C. Estimation of the generation rate of different types of plastic wastes and possible revenue recovery from informal recycling. Waste Manag. 2018;79:781-790. DOI:10.1016/j.wasman.2018.08.045.PMID: 30343811

26. Das B, Bhave PV, Sapkota A, Byanju RM. Estimating emissions from open burning of municipal solid waste in municipalities of Nepal. Waste Manag. 2018;79:481-490. DOI:10.1016/j.wasman.2018.08.013.Epub 2018 Aug 13. PMID: 30343779

27. Kalogiannidou K, Nikolakopoulou E, Komilis D. Generation and composition of waste from medical histopathology laboratories. Waste Manag. 2018;79: 435-442.

DOI:10.1016/j.wasman.2018.08.012.PMID: 30343773

28. Nie E, Zheng G, Shao Z, Yang J, Chen T. Emission characteristics and health risk assessment of volatile organic compounds produced during municipal solid waste composting. Waste Manag. 2018; 79:188-195.

DOI:10.1016/j.wasman.2018.07.024.PMID: 30343745

(C) 2022 Adebisi et al.; This is an Open Access article distributed under the terms of the Creative Commons Attribution License (http://creativecommons.org/licenses/by/4.0), which permits unrestricted use, distribution, and reproduction in any medium, provided the original work is properly cited.

Peer-review history:

The peer review history for this paper can be accessed here: https://www.sdiarticle5.com/review-history/70211 